\title{
Evaluation of Intermediate MBT Degradation Products by a Heterogeneous Fenton-like Reaction
}

ISSN: 2578-0255

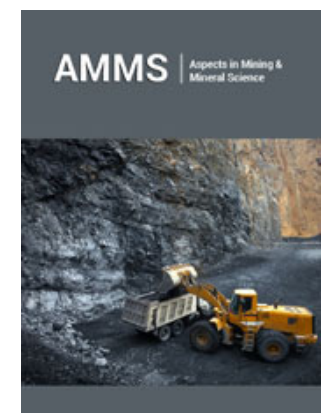

*Corresponding author: Adriana Lau da Silva Martins, Department of Engineering, Brazil

Submission: 眥 February 11, 2020

Published: 址 March 11, 2020

Volume 4 - Issue 4

How to cite this article: Adriana Lau da Silva Martins, Fabiana Valéria da Fonseca, Lídia Yokoyama. Evaluation of Intermediate MBT Degradation Products by a Heterogeneous Fenton-like Reaction. Aspects Min Miner Sci.4(4). AMMS.000593.2020. DOI: 10.31031/AMMS.2020.04.000593

Copyright@ Adriana Lau da Silva Martins, This article is distributed under the terms of the Creative Commons Attribution 4.0 International License, which permits unrestricted use and redistribution provided that the original author and source are credited.

\author{
Adriana Lau da Silva Martins ${ }^{1,2 *}$, Fabiana Valéria da Fonseca $^{2}$ and Lídia \\ Yokoyama $^{2}$ \\ ${ }^{1}$ Department of Engineering, Brazil \\ ${ }^{2}$ School of Chemistry, Brazil
}

\begin{abstract}
Mercaptobenzothiazole is a product widely applied in the industry, despite being resistant to biodegradation and producing certain recalcitrant by-products. The most applied oxidation process for the recalcitrant consists in Advanced Oxidative Processes (AOPs). Herein, a Fenton-like reaction was applied, using iron residues from the sludge step of mining operations. The applied technique was efficient and the formation of MBT by products was detected.
\end{abstract}

Keywords: Fenton-like; Mercaptobenzothiazole; AOP; Intermediate of MBT

Introduction

Mercaptobenzothiazole (MBT) is widely used in industries as an accelerator for the rubber vulcanization and as a fungicide, bactericide, preservative or corrosion inhibitor. This compound is a selective collector for copper and zinc sulfide, and an adequate collector for oxidized minerals. MBT is very resistant to biodegradation, and many of its degradation products are recalcitrant Bess et al. [1]. Advanced Oxidative Processes (AOPs) have become increasingly promising and efficient in promoting the degradation of these recalcitrant substances. AOPs generate highly reactive hydroxyl radicals $(\bullet \mathrm{OH})$, which display a high potential oxidation pattern of $2.8 \mathrm{~V}$. Due to their high reactivity, they are often able to oxidize various recalcitrant organic substances, which can lead to the total or partial mineralization of pollutants in water. AOPs, when combined with other forms of treatment, can be efficient and economically viable Elsellami et al. [2]. In this context, the aim of this study is to evaluate MBT intermediates formed during MBT degradation by an advanced oxidative process.

\section{Material and Methods}

An iron residue was used, in the form of a powder from the de-lamination step of the iron ore beneficiation process donated by the VALE-Araxá Unit, with iron concentration ranging between 58.6 to $67.4 \%$ as analyzed by DRX, in a granulometric range of 74 to $<44 \mathrm{~mm}$. The zero-charge point ( $\mathrm{pHzc}$ ) of this residue is 7. The persistent compound MBT was assessed in an aqueous medium at a concentration of $100 \mathrm{mgL}_{-1}$. Ideal conditions for a Fenton-like reaction were obtained through experimental tests carried out in previous studies $[3,4]$ as follows: $[\mathrm{MBT}]=100 \mathrm{mgL}_{-1}$, [residue $]=3 \mathrm{gL}_{-1},\left[\mathrm{H}_{2} \mathrm{O}_{2}\right]=6.25 \mathrm{mgL}_{-1}$ and $25 \mathrm{mgL}_{-1}, \mathrm{~T}=25 \stackrel{\circ}{\circ} \mathrm{C}, \mathrm{t}=60$ minutes and $\mathrm{pH}=3$. Mercaptans were identified through UV spectrophotometry, through the following peaks: benzothiazole-2-sulfonate- $\mathrm{BTSO}_{3}(267 \mathrm{~nm}), \mathrm{MBT}(320 \mathrm{~nm}), 2$-mercaptobenzimidazoleMBI (299nm), 2-mercaptobenzoxazole-MBO (290nm), 2-mercaptopiridine-MP (341nm) and PTM $(315 \mathrm{~nm})$. The Fenton-like reaction was carried out in a $500 \mathrm{~mL}$ conical flask containing $300 \mathrm{~mL}$ of an MBT solution $\left(100 \mathrm{mgL}_{-1}\right)$, followed by the addition of the iron mining residue $\left(3 \mathrm{gL}_{-1}\right)$, while stirring in a shaker. Subsequently, $\mathrm{H}_{2} \mathrm{O}_{2}\left(6.25 \mathrm{mgL}_{-1}\right.$ and $\left.25 \mathrm{mgL}_{-1}\right)$ was added, beginning and maintaining the reaction for 1 hour. After this period, aliquots were removed and filtered and solution absorbances were evaluated using a UV-Mini-Shimadzu 1240 spectrophotometer. 


\section{MBT Degradation Assessments by AOPs}

Increasing the hydrogen peroxide concentration from $6.25 \mathrm{mgL}$. ${ }_{1}$ to $25 \mathrm{mgL}_{-1}$ in the Fenton-like reaction at $\mathrm{pH}=3$, $[\mathrm{MBT}]=100 \mathrm{mgL}_{-1}$, [residue] $=3 \mathrm{gL}_{-1}, 200 \mathrm{rpm}, \mathrm{T}=25{ }^{\circ} \mathrm{C}$ and 1 hour reaction time was relevant in decreasing MBT derivative concentrations to below $1 \mathrm{mgL}_{-1}$ (Figure 1). The MBT derivatives detected in the postFenton-like solution through UV spectrophotometry were MBI, MBO, MP and para-tolilmercaptan (PTM). The presence MBT oxidation products (intermediates) was also detected, namely 2-hydroxy benzothiazole (OBT), benzothiazole (BT), and $\mathrm{BTSO}_{3}$. No traces of the OBT and BT intermediates were detected in the post Fenton-like solution, although the $\mathrm{BTSO}_{3}$ intermediate was detected at approximately $1 \mathrm{mgL}_{-1}$, at both hydrogen peroxide concentrations (6.25 and $25 \mathrm{mgL}_{-1}$ ), thus proving its persistence. Bao et al. [5] also detected the formation of BT and OBT intermediates when degrading MBT by gamma irradiation, although they observed that these products are easily mineralized by biological treatments, this study only identified the presence or absence of intermediates, without quantifying them.

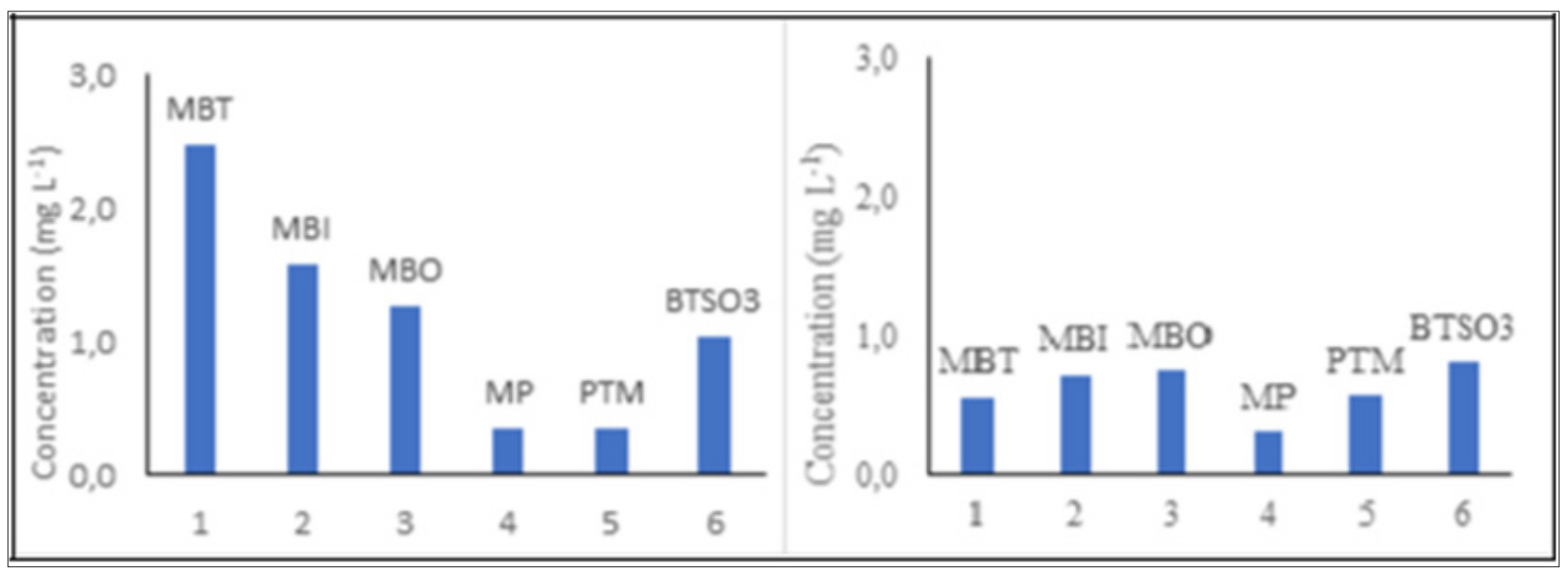

Figure 1: MBT degradation intermediates in the Fenton-like post solution.

Conditions:

(a) $\left[\mathrm{H}_{2} \mathrm{O}_{2}\right]=6.25 \mathrm{mgL}_{-1}, \mathrm{pH}=3,[\mathrm{MBT}]=100 \mathrm{mgL}^{-1}$, [residue $]=3 \mathrm{gL}^{-1}, 20 \mathrm{rpm}, \mathrm{T}=25{ }^{\circ} \mathrm{C}, 1$ hour reaction time and

(b) $\left[\mathrm{H}_{2} \mathrm{O}_{2}\right]=25 \mathrm{mgL}^{-1}, \mathrm{pH}=3,[\mathrm{MBT}]=100 \mathrm{mgL}^{-1}$, [residue $]=3 \mathrm{gL}^{-1}, 200 \mathrm{rpm}, \mathrm{T}=25^{\circ} \mathrm{C}, 1$ hour reaction time.

Therefore, it is possible to associate decreased MBT concentrations in the investigated solution after increasing the hydrogen peroxide concentration of $6,25 \mathrm{mgL}_{-1}$ to $25 \mathrm{mgL}_{-1}$ (Figure $1 \mathrm{a} \& 1 \mathrm{~b}$ ) to greater MBT reactivity in relation to MBI, followed by MBO on the residue surface. Habibi et al. [6] studied the photocatalytic oxidation of a rubber industry effluent that uses MBT as a vulcanization process accelerator through the application of heterogeneous $\mathrm{TiO}_{2}$ catalyst in a photocatalytic reactor. Herein, 2-mercaptobenzothiazole (MBT) and its derivatives, MBI, MBO, MP, mercaptanpara-tolyl (PPM) were detected in the assessed effluent. MBT oxidation resulted in the presence of an intermediate compound, $\mathrm{BTSO}_{3}$. It is observed that despite the MBT oxidation technique being another one referred to in this article, the authors mentioned above also found the formation of intermediates in the resulting solutions, which justifies the reliability of the Fentonlike technique when compared with photocatalytic oxidation and irradiation.

\section{Conclusion}

MBT degradation through AOPs using a heterogeneous Fentonlike technique was thus deemed efficient, as the initial MBT concentration of $100 \mathrm{mgL}_{-1}$ decreased to approximately $2.5 \mathrm{mgL}_{-1}$ with the addition of $6.25 \mathrm{mgL}_{-1}$ of $\mathrm{H}_{2} \mathrm{O}_{2}$, and an MBT concentration of $1.0 \mathrm{mgL}_{-1}$ to $25 \mathrm{mgL}_{-1} \mathrm{H}_{2} \mathrm{O}_{2}$ soon led to the reduction in the concentration of other formed intermediates, except for $\mathrm{BTSO}_{3}$, which remained constant.

\section{References}

1. Bess P, Combourieu B, Boyse G, Sancelme M, Dewever H (2001) From benzothiazole to 2-hydroxybenzothiazole. Appl Environ Microbiol 67(4): 1412-1417.

2. Elsellami L, Chartron V, Vocanson F, Conchon P, Felix C, et al. (2009) Coupling process between solid-liquid extraction of amino acids by calixarenes and photocatalytic degradation. Journal of Hazardous Materials 166(2-3): 1195-1200.

3. Martins ALS, Teixeira LAC, Fonseca VF, Yokoyama L (2016) Evaluation of the mercaptobenzothiazole degradation by combined adsorption process and Fenton reaction using iron mining residue. Environmental Technology 38(16).

4. Martins ALS (2017) Study of the heterogeneous Fenton-like process using waste from the processing of iron as a catalyst in the degradation of Mercaptobenzothiazole (MBT).

5. Bao Q Chen L, Tian J, Wang J (2014) Degradation of 2-mercaptobenzothiazole in aqueous solution by gamma irradiation. Radiation Physics and Chemistry 103: 198-202.

6. Habibi MH, Tangestaninejad S, Yadollahi B (2001) Photocatalytic mineralisation of mercaptans as environmental pollutants in aquatic system using $\mathrm{TiO}_{2}$ suspension. Appl Catal B Environ 33: 57-63. 
For possible submissions Click below:

Submit Article 